WRI-05-R014

\title{
MATERIALS OF GASIFICATION
}

Final Report for Base Project Task 1.9

Under DE-FC26-98FT40322

September 2005

U.S. Department of Energy

National Energy Technology Laboratory

Morgantown, West Virginia

\author{
By \\ Western Research Institute \\ Laramie, Wyoming
}




\section{DISCLAIMER}

This report was prepared as an account of work sponsored by an agency of the United States Government. Neither the United States Government nor any agencies thereof, nor any of its employees makes any warranty, expressed or implied, or assumes any legal liability or responsibility for the accuracy, completeness, or usefulness of any information, apparatus, product, or process disclosed or represents that its use would not infringe on privately owned rights. Reference herein to any specific commercial product, process, or service by trade name, trademark, manufacturer, or otherwise does not necessarily constitute or imply endorsement, recommendation, or favoring by the United States Government or any agency thereof. The views and opinions of authors expressed herein do not necessarily state or reflect those of the United States Government or any agency thereof. 


\begin{abstract}
The objective of this project was to accumulate and establish a database of construction materials, coatings, refractory liners, and transitional materials that are appropriate for the hardware and scale-up facilities for atmospheric biomass and coal gasification processes. Cost, fabricability, survivability, contamination, modes of corrosion, failure modes, operational temperatures, strength, and compatibility are all areas of materials science for which relevant data would be appropriate. The goal will be an established expertise of materials for the fossil energy area within WRI. This would be an effort to narrow down the overwhelming array of materials information sources to the relevant set which provides current and accurate data for materials selection for fossil fuels processing plant.
\end{abstract}

A significant amount of reference material on materials has been located, examined and compiled. The report that describes these resources is well under way. The reference material is in many forms including texts, periodicals, websites, software and expert systems. The most important part of the labor is to refine the vast array of available resources to information appropriate in content, size and reliability for the tasks conducted by WRI and its clients within the energy field. A significant has been made to collate and capture the best and most up to date references. The resources of the University of Wyoming have been used extensively as a local and assessable location of information. As such, the distribution of materials within the UW library has been added as a portion of the growing document.

Literature from recent journals has been combed for all pertinent references to high temperature energy based applications. Several software packages have been examined for relevance and usefulness towards applications in coal gasification and coal fired plant. Collation of the many located resources has been ongoing. Some web-based resources have been examined. 


\section{TABLE OF CONTENTS}

\section{Page}

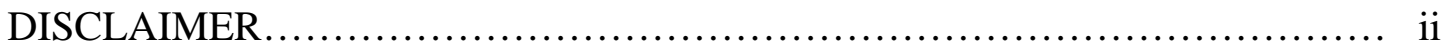

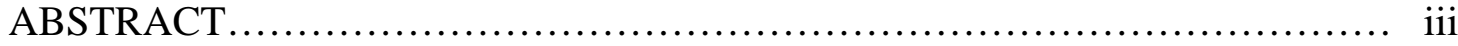

EXECUTIVE SUMMARY ...................................................

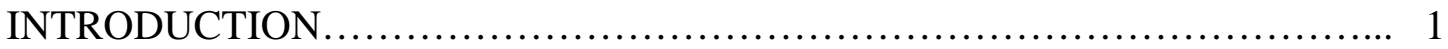

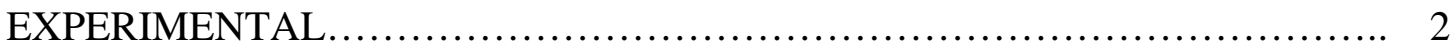

RESULTS AND DISCUSSION ............................................... 2

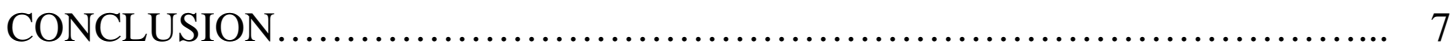

APPENDIX A......................................................................... 9

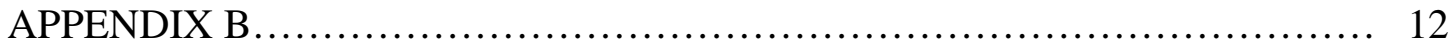




\section{EXECUTIVE SUMMARY}

There are references that state that there are over 100,000 materials available for selection for use in manufactured components. The number of possibilities would seem to make the materials selection process overwhelming. The Energy Production and Generation Business Unit of the Western Research Institute is focused on fossil fuels and related industries such as biomass use for energy. There has been a need within the business unit for an organized expertise in materials selection, materials testing, and materials consulting for energy related plant and hardware.

The objective of this project was to accumulate and establish a database of construction materials, coatings, refractory liners, and transitional materials that are appropriate for the hardware and scale-up facilities for atmospheric biomass and coal gasification processes. Cost, fabricability, survivability, contamination, modes of corrosion, failure modes, operational temperatures, strength, and compatibility are all areas of materials science for which relevant data would be appropriate. The goal will be an established expertise of materials for the fossil energy area within WRI. This would be an effort to narrow down the overwhelming array of materials information sources to the relevant set which provides current and accurate data for materials selection for fossil fuels processing plant.

A significant amount of reference material on materials has been located, examined and compiled. The report that describes these resources is well under way. The reference material is in many forms including texts, periodicals, websites, software and expert systems. The most important part of the labor is to refine the vast array of available resources to information appropriate in content, size and reliability for the tasks conducted by WRI and its clients within the energy field. A significant has been made to collate and capture the best and most up to date references. The resources of the University of Wyoming have been used extensively as a local and assessable location of information. As such, the distribution of materials within the UW library has been added as a portion of the growing document.

Literature from recent journals has been combed for all pertinent references to high temperature energy based applications. Several software packages have been examined for relevance and usefulness towards applications in coal gasification and coal fired plant. Collation of the many located resources has been ongoing. Some web-based resources have been examined. An appendix has been attached which describes the extent of available materials selection resources located and cataloged. 


\section{INTRODUCTION}

There are references that state that there are over 100,000 materials available for selection for use in manufactured components. The number of possibilities would seem to make the materials selection process overwhelming. The Energy Production and Generation Business Unit of the Western Research Institute is focused on fossil fuels and related industries such as biomass use for energy. There has been a need within the business unit for an organized expertise in materials selection, materials testing, and materials consulting for energy related plant and hardware. The collection to be prepared within this project is intended to provide a starting point for the business unit and other WRI personnel for gathering the necessary information to make informed and effective materials choices for energy based applications. The objective is to be able to divide the 100,000 available materials into appropriate classes and easily eliminate the vast majority of materials inappropriate for the application. The smaller the remaining pile of available materials and the more complete the information for making the selection, the faster the process will be and the more certain the engineer will be that the correct choice was made in the end.

There is no need for each engineer to be an expert in materials science. The goal of this collection will be to allow engineers to be able to self educate in the area of materials for energy applications to the extent that they could narrow the selection to a class or set of options which could then be discussed with salespeople or technical contacts. At the point of materials selection, the engineer may not know the answer to the best choice, but he must be able to ask the right questions and be fore armed with the information necessary to make the appropriate selection. The chosen material should meet the criteria for performance and manufacturability while being cost effective and performing safely.

Automotive design engineers are told not to reject any possible material class before a part specification is developed. Each new component is considered independently without the prejudice of how a similar part may have been specified previously. This has led to many new materials incorporated into vehicles; materials like sheet molded composites, magnesium castings, carbon fiber structures, more and more plastics, aluminum, and lightweight materials. In an automobile where weight and cost may be the most important materials characteristics, this open approach makes a great deal of sense. To choose a structural steel takes as much justification as a carbon fiber component. In the world of energy plant where high temperatures, high pressures, highly oxidizing or reducing environments, sulfur, steam, particulates, and molten slag could be present, the materials selection process can afford to be more prejudiced by previous experience. In fact, the majority of materials selection choices may be mandated by plant and research experience conducted over the past 100 years. Although the history of 
gasification and combustion are a great deal older than 100 years, it is only in the past 100 years that materials have been scientifically studied with respect to composition and processing for properties. It is not out of hand that whole classes of materials can be withdrawn from consideration for use in gasification and combustion plant, but rather that the demands of the conditions are so stringent that a large amount of materials could not meet minimum performance criteria. For that reason the following materials and classes will not be discussed in this document:

1. Polymers and polymer matrix composites

2. Aluminum alloys

3. Titanium alloys

4. Magnesium alloys

5. Copper alloys

6. Alloys of lead, tin, zinc, beryllium, bismuth, vanadium, or precious metals

By eliminating that list of materials, nearly two volumes of the three volume set CRC Elsevier Materials Selector have been set aside. That still leaves nearly 800 pages of data in that set relevant to materials for applications in gasification and combustion. Materials of interest and discussed further in this document concern:

1. Cast irons

2. Carbon steels

3. Low alloy steels

4. Alloy steels

5. Stainless steels

6. Nickel alloys

7. Cobalt alloys

8. Refractory metals

9. Ceramics

10. Coatings

The first section of the collection includes the currently available resources at WRI and the University of Wyoming library system relevant to materials in high temperature plant. These resources are primarily books and reference texts, but include microfiche, periodicals, and some online access to databases.

The next section describes the environments in which materials relevant to this study must operate: combustion and gasification environments with all the associated chemical and physical characteristics found there. The third section of the document lists materials properties of concern in the materials selection process for combustion and gasification. This is followed by a description of the materials selection process and 
factors to be considered during that practice. The last sections are materials notes, a bibliography and a glossary of terms.

\section{EXPERIMENTAL}

Accumulate and establish a database of construction materials, coatings, refractory liners, and transitional materials that are appropriate for the hardware and scale-up facilities for atmospheric biomass and coal gasification processes. Cost, fabricability, survivability, contamination, modes of corrosion, failure modes, operational temperatures, strength, and compatibility are all areas of materials science for which relevant data would be appropriate. The goal will be not only a database, but an established expertise of materials for the fossil energy area within WRI. This would be an effort to narrow down the overwhelming array of materials information sources to the relevant set which provides current and accurate data for materials selection for fossil fuels processing plant.

Milestones:

- Identify best sources for materials information in the areas of metallurgy, refractories, and coatings for use in gasification and processing plant hardware in the form of published references, available databases, and industry experts.

- Assemble and catalog the materials information in a searchable form.

- Write a report on the materials database for WRI and current JSR customers.

\section{RESULTS AND DISCUSSION}

\section{Combustion Environments}

The combustion environment for coal or biomass is an extreme and complex situation for materials science. The temperature ranges are high, thermal cycling is inevitable, environments can be reducing or highly oxidizing depending on operation conditions, pressures can range quite high, chemical contaminants can be corrosive, and component lifetimes are expected to be in the 10,000's of hours.

\section{Oxidizing/Reducing Environments}

The general reaction in a coal combustor is carbon plus oxygen going to carbon dioxide. As the coal is not pure carbon, and air is commonly used instead of pure oxygen, it is not a case of using exact stoichiometry of carbon and oxygen in a single point in space. Much of the intended variation in reducing and oxidizing environments within a combustor is due to the lesser elements found in coal including nitrogen and sulfur containing species. Nitrogen containing compounds within coal include ammonia 
and cyanide based species. Direct oxidation of these compounds will lead to nitrogen oxide species (generally and collectively known as $\mathrm{NO}_{\mathrm{x}}$ ). Most $\mathrm{NO}_{\mathrm{x}}$ species are environmentally harmful and emission of these species is regulated. If ammonia and cyanide compounds are thermally decomposed in a more reducing environment, the more of the nitrogen as $\mathrm{N}_{2}$ is formed, and less $\mathrm{NO}_{\mathrm{x}}$ species are formed. If the entire combustion was run fuel rich, there would be less than total usage of the energy in the fuel, and carbon monoxide emissions, which are also regulated, would be too high. Additionally, sulfur from the coal would be more likely to be emitted as hydrogen sulfide that causes both materials problems and environmental problems. The answer to this situation is to inject a certain amount of oxygen or air at the bottom of the combustor where a slightly fuel rich environment (reducing) is maintained. Higher up the combustor a second injection of oxygen occurs which combusts the remaining fuel and leads to a net oxygen content of $3-4 \%$ in the exit gas. All of the fuel is combusted, and $\mathrm{CO}, \mathrm{NO}_{\mathrm{x}}$ and $\mathrm{H}_{2} \mathrm{~S}$ are all controlled within limits.

The distribution of materials within oxidizing and reducing environments is defined by location within the reactor, and to some extent, the operational cycle with respect to start up. Materials usually see a consistent environment, even if that environment varies within the reactor. This simplifies the materials selection process to some extent in that environments are usually predictable if not benign. Although high temperature oxidation can be a significant problem for metals within the combustor, the presence of a modest oxygen partial pressure allows many alloys to maintain a passivating oxide surface. In reducing environments, particularly where there is some erosion from solids, an alloy may not produce a protective oxide layer that could prevent significant metal loss.

In a combustion atmosphere where deposits of ash may build up on surfaces, it is possible to generate local surface areas where the presence of unburned coal and poor gas exchange lead to reducing conditions.

\section{Pressure and Temperature}

Pressurized fluidized bed combustors exist but are uncommon. The pressure in the majority of coal combustion reactors is near atmospheric pressure. This pressure difference between gasification and combustion reactors is significant with respect to materials performance. At atmospheric pressure, gases such as steam, carbon monoxide and carbon dioxide are significantly less corrosive. Dew points are also higher at atmospheric pressure.

Temperature control in a coal combustor is essential to maintain efficiency and vessel integrity. Altering the oxidation rate controls the maximum temperature in the combustor. This rate is controlled by oxygen or air feed rates. The temperature is 
highest above the coal burners and the center of the combustor. That gas temperature value could reach $1400^{\circ} \mathrm{C}$. The incoming air helps to keep the burners cooler than the gas temperature. A refractory liner keeps the temperature of the walls moderated, which protects the combustor walls. If the combustor operates as a boiler, there is a water wall that is essentially a tubular heat exchanger within the combustor. The steam within the water wall controls the temperature of the alloy of the heat exchanger. Steam flow rates are also used to control temperatures within superheater and reheater tubes at the top of the combustor, and thus the temperature of the combustor gas downstream of the heat exchangers. In previous generation combustors, the superheaters were limited to $550^{\circ} \mathrm{C}$. In advanced reactors, temperatures of superheaters are taken to $800^{\circ} \mathrm{C}$ to increase overall thermal efficiency.

\section{Gasification Environments}

The gasification environment has significant differences from the combustion environment with respect to materials. These differences include carbon dioxide/carbon monoxide content, oxygen partial pressure, hydrogen concentration and temperature distribution. Each one of these differences can be a critical factor in materials performance.

\section{Reducing Atmosphere}

Although gasification may be assisted by the addition of oxygen or air, the net atmosphere within the reactor is reducing. With a carbon monoxide to carbon dioxide ratio of $5: 1$ and at a temperature of $800^{\circ} \mathrm{C}$, the equilibrium partial pressure of oxygen is approximately $10^{-15}$ atmospheres. Given that the hydrogen concentration may be as high as $30 \%$, oxides can reduce to metals and protective metal oxides cannot reform. In a reducing environment, sulfur, which is generally in the form of $\mathrm{SO}_{2}$ in combustion, is more likely to exist as $\mathrm{H}_{2} \mathrm{~S}$ in the gasifier.

\section{Temperature and Pressure}

Coal gasification technologies produce intermediate BTU syngas using oxygen and steam. Four gasifier designs include slagging fixed bed, non-slagging fixed bed, fluidized bed and entrained flow. The slagging gasifiers operate at such high temperatures that internal metal components are avoided, using refractory materials as liners. Alloy components are required downstream in the heat recovery portions of the plant. In non-slagging bed gasifiers, alloy components may be used.

\section{$\underline{\text { Materials Selection Process }}$}


Functional requirements: Capacity, size, weight, safety, codes, service life, reliability, ease of operation, ease of repair, initial cost, operating cost, service environment, noise level, and pollution.

Materials requirements: strength, ductility, toughness, stiffness, density, corrosion resistance, wear resistance, cost, availability, fatigue properties, creep properties, weldability

\section{Materials Selection Advice}

"For applications in coal gasification plants, for raw gas heat exchangers in the temperature range $400-700^{\circ} \mathrm{C}$, chromia forming iron or nickel based materials are the usual choice. Fe-Cr alloys must have alloy contents greater than $17 \%$. Ni-Cr alloys should have $\mathrm{Cr}$ contents greater than $20 \%$ to form a protective layer... A popular Fe-Cr$\mathrm{Ni}$ material is Alloy 800 (Fe-20Cr-32Ni-Al-Ti)... At temperatures between $900-1200^{\circ} \mathrm{C}$, alumina forming alloys are preferred as chromia becomes volatile at this temperature.”

H. Grabke in Materials for Coal Gasification Power Plant, Butterworth-Heinemann, page 23.

\section{ASM Materials Solutions Conference and Exposition, Columbus, OH Oct. 18-20 ${ }^{\text {th }}, 2004$}

Challenges for High Temperature Alloys in Aerospace, Land Based Gas Turbines, Power \& Transportation Symposium

Materials Issues in the Next Generation Coal Fired Power Plants, R. Viswanathan, EPRI

Boilers and heavy wall components of supercritical plant (above $538^{\circ} \mathrm{C}$ and $3400 \mathrm{psi}$ ) require special materials. Austenitic stainless steels have high thermal expansion that lead to thermal fatigue in thick sections. Ferritics are preferred for that reason. The requirements for those materials including looking at issues including creep, thermal fatigue, ability to weld, ability to fabricate, toughness, fireside corrosion, steam-side oxidation, and exfoliation. Alloys suggested for these applications include SAVE12 (12CrWCoVNb), NF12, TB12, P122, HCM12A, T23, T91 and EM12. In these alloys, $\mathrm{Cr}$ content is for corrosion control; $\mathrm{V}, \mathrm{Nb}$ and $\mathrm{N}$ are for creep reduction; $\mathrm{W}, \mathrm{Mo}$ and low carbon assist welding, and $\mathrm{Si}$ is for toughness. Below $593^{\circ} \mathrm{C}, \mathrm{P} 91$ is recommended. At $620^{\circ} \mathrm{C}$, P92, p122, or E9U is recommended. At $630^{\circ} \mathrm{C}$, NF12 or SAVE12 is recommended. For higher temperatures a new alloy, Inconel 740, is under development. 
Weld Overlay Coatings for Corrosion Protection in Boilers with low $\mathrm{NO}_{\underline{x}}$ Burners, $\mathrm{J}$. Dupont, Lehigh University

The water-wall within a boiler is exposed to extreme conditions and often requires additional measures to prevent failure through corrosion. Weld overlays are used to add additional oxidation and sulphidation resistance. Testing has shown that FeCrAl alloys make good weld overlay materials. Chromium oxides and aluminum oxides that form are stable and resistive. The balance of chromium and aluminum in the alloys depends on weldability and the propensity for hydrogen cracking. The acceptable alloys form a triangle with one leg being the concentration of chromium between 0 and $12 \mathrm{wt} \%$, and the second leg being the concentration of aluminum between 5 and 14wt\%. Too much aluminum and the weld cracks. The optimum alloy was determined to be Fe10Al5Cr. Molybdenum is kept out of the alloy as molybdenum sulfide forms instead of the preferred chromium oxide.

Alloy Development for Advanced Waste to Energy Boilers, Y. Kawahara, Mitsubishi Heavy Industries

Waste-to-energy boiler systems have higher corrosion resistance requirements due to high concentrations of alkalai metal, lead, sulfates and chlorides in their fuels. Up to $20 \%$ os ash deposited on superheater tubes may be liquid salt deposits. Superheater tubes up to $450^{\circ} \mathrm{C}$ may be of $310 \mathrm{SS}$ or Incoloy 825 . Between 450 and $500^{\circ} \mathrm{C}$, Inconel 625, JHN24, or MAC-F are recommended. Water-wall weld overlay alloys may be $\mathrm{NiCrSiB}$ or an Inconel 625 spray.

\section{CONCLUSIONS}

A significant amount of reference material on materials has been located, examined and compiled. The report that describes these resources is well under way. The reference material is in many forms including texts, periodicals, websites, software and expert systems. The most important part of the labor is to refine the vast array of available resources to information appropriate in content, size and reliability for the tasks conducted by WRI and its clients within the energy field. A significant has been made to collate and capture the best and most up to date references. The resources of the University of Wyoming have been used extensively as a local and assessable location of information. As such, the distribution of materials within the UW library has been added as a portion of the growing document.

Literature from recent journals has been combed for all pertinent references to high temperature energy based applications. Several software packages have been examined for relevance and usefulness towards applications in coal gasification and coal 
fired plant. Collation of the many located resources has been ongoing. Some web-based resources have been examined. Appendix A has been attached which describes the extent of available materials selection resources located and cataloged. Appendix B includes some specific materials notes not included in the results and discussion section. 


\section{APPENDIX A}

\section{Bibliography of Materials Science for Power Plants at UW Library}

\begin{tabular}{|c|c|c|c|}
\hline $\begin{array}{l}\text { Library } \\
\text { Reference }\end{array}$ & Authors & Title & Comments \\
\hline $\begin{array}{l}\text { TA418.26 M43 } \\
2000\end{array}$ & $\begin{array}{l}\text { G. Meetham, M. } \\
\text { Van de Voorde }\end{array}$ & $\begin{array}{l}\text { Materials for High } \\
\text { Temperature Applications, } \\
\text { Springer Berlin }\end{array}$ & $\begin{array}{l}\text { Mostly concepts, few facts, } \\
\text { historical textbook more than } \\
\text { reference }\end{array}$ \\
\hline $\begin{array}{l}\text { TA418.24 J26 } \\
1986\end{array}$ & $\begin{array}{l}\text { K. Iida, A. } \\
\text { McEvily }\end{array}$ & $\begin{array}{l}\text { Advanced Materials for } \\
\text { Severe Service } \\
\text { Applications, Elsevier } 1987\end{array}$ & $\begin{array}{l}\text { Japanese Conf. Proceedings, } \\
\text { fatigue and cracking, turbine } \\
\text { rotors }\end{array}$ \\
\hline $\begin{array}{l}\text { TA418.26 I533 } \\
1995\end{array}$ & $\begin{array}{l}\text { K. Natesan, P. } \\
\text { Ganesen, G. Lai }\end{array}$ & $\begin{array}{l}\text { Heat Resistant Materials II, } \\
\text { ASM }\end{array}$ & $\begin{array}{l}\text { Some excellent alloy versus coal } \\
\text { gasification environment studies, } \\
\text { plus test methods. There are also } \\
\text { several papers on materials in } \\
\text { MSW combustion. This book and } \\
\text { the next one are among the best in } \\
\text { terms of real data and suggested } \\
\text { solutions to problems. }\end{array}$ \\
\hline $\begin{array}{l}\text { TA418.26 H53 } \\
1990\end{array}$ & E. Bachelet & $\begin{array}{l}\text { High Temperature Materials } \\
\text { for Power Engineering, } \\
\text { Parts I+II Kluwer Academic }\end{array}$ & $\begin{array}{l}\text { Part I has several excellent } \\
\text { sections on metals used in coal } \\
\text { gasification plant. There are } \\
\text { comparisons of corrosion rates for } \\
\text { different alloys in real } \\
\text { environments ranging from carbon } \\
\text { steels to nickel superalloys. } \\
\text { Among the three best texts so far } \\
\text { located on this subject. }\end{array}$ \\
\hline $\begin{array}{l}\text { TA418.26 P8 } \\
1967\end{array}$ & Y. Touloukian & $\begin{array}{l}\text { Thermophysical Properties } \\
\text { of High Temperature Solid } \\
\text { Materials Vol 1-6 }\end{array}$ & $\begin{array}{l}\text { 1-elements, 2-non-ferrous, 3- } \\
\text { ferros, 4-oxides, 5-non oxides, 6- } \\
\text { intermetallics, density, Mp, } \Delta \mathrm{Hf} \text {, } \\
\Delta \text { Hvap, resistivity, Cp, thermal } \\
\text { conductivity, diffusivity, CTE, } \\
\text { thermal radiation, vapor pressure }\end{array}$ \\
\hline $\begin{array}{l}\text { TA403 C74 } \\
1976\end{array}$ & C. Stein & $\begin{array}{l}\text { Critical Materials Problems } \\
\text { in Energy Production, } \\
\text { Academic Press }\end{array}$ & $\begin{array}{l}\text { Mostly fusion and alternate } \\
\text { energy, but Section V on coal. } \\
\text { Quite a good general description } \\
\text { of materials issues. One section of } \\
\text { gasification catalysts not yet read. }\end{array}$ \\
\hline $\begin{array}{l}\text { TA467 H93 } \\
1985\end{array}$ & $\begin{array}{l}\text { R. Oriani, J. Hirth, } \\
\text { M. Smialowski }\end{array}$ & $\begin{array}{l}\text { Hydrogen Degradation of } \\
\text { Ferrous Alloys, Noyes Pub. }\end{array}$ & $\begin{array}{l}\text { Fe-H, Ni-H, cracking and failure, } \\
\text { resistant steels }\end{array}$ \\
\hline $\begin{array}{l}\text { TA472 E63 } \\
1982\end{array}$ & ASM & $\begin{array}{l}\text { Engineering properties of } \\
\text { Steel, ASM reference } \\
\text { standard }\end{array}$ & Properties and tables \\
\hline $\begin{array}{l}\text { TA479.s7 A76 } \\
1981\end{array}$ & A. Khane & $\begin{array}{l}\text { Ferritic Steels for High } \\
\text { Temperature } \\
\text { Applications }\end{array}$ & $\begin{array}{l}\text { Although strictly about 9Cr- } \\
\text { 1Mo steels, there is one } \\
\text { excellent comparison paper } \\
\text { concerning many alloys in coal } \\
\text { gasification environments }\end{array}$ \\
\hline $\begin{array}{l}\text { TA479.s7 H28 } \\
1977\end{array}$ & $\begin{array}{l}\text { D. Peckner, I. } \\
\text { Bernstein }\end{array}$ & $\begin{array}{l}\text { Handbook of Stainless } \\
\text { Steel, Mcgraw Hill }\end{array}$ & $\begin{array}{l}\text { Chapter on power plant with } \\
\text { SS suggestions (SS316, 321, } \\
\text { 347) }\end{array}$ \\
\hline
\end{tabular}




\begin{tabular}{|c|c|c|c|}
\hline $\begin{array}{l}\text { TA418.26 } \\
\text { S874 } 1989\end{array}$ & T. Rhys Jones & $\begin{array}{l}\text { Surface Stability, } \\
\text { Institute of Metals }\end{array}$ & $\begin{array}{l}\text { One chapter on corrosion } \\
\text { protection in power plants }\end{array}$ \\
\hline $\begin{array}{l}\text { TA459 R65 } \\
1980\end{array}$ & R. Ross & $\begin{array}{l}\text { Metallic Materials } \\
\text { Specification Handbook, } \\
\text { Spon London }\end{array}$ & $\begin{array}{l}\text { Composition and properties of } \\
\text { trade name steels and alloys }\end{array}$ \\
\hline $\begin{array}{l}\text { TA459 S494 } \\
1986\end{array}$ & H. Boyer & $\begin{array}{l}\text { Selection of Materials for } \\
\text { Component Design, ASM } \\
\text { Ohio }\end{array}$ & $\begin{array}{l}\text { Section IV Generating Plant } \\
\text { Components, minimal information } \\
\text { but good table on coal plant } \\
\text { materials p183 }\end{array}$ \\
\hline $\begin{array}{l}\text { TA491 C66 } \\
1985\end{array}$ & R. Sisson & $\begin{array}{l}\text { Coatings and Bimetallics } \\
\text { for Aggressive } \\
\text { Environments, ASM }\end{array}$ & $\begin{array}{l}\text { Useful for information on clad } \\
\text { plate and co-extruded tubes in } \\
\text { gasifiers }\end{array}$ \\
\hline $\begin{array}{l}\text { TA485 S65 } \\
1979\end{array}$ & ASM & $\begin{array}{l}\text { Source Book on Materials } \\
\text { for Elevated Temperature } \\
\text { Applications }\end{array}$ & $\begin{array}{l}\text { One good article on petrochemical } \\
\text { and refining copied p55 }\end{array}$ \\
\hline $\begin{array}{l}\text { TJ291 G744 } \\
1953\end{array}$ & ASME & $\begin{array}{l}\text { History of ASME Boiler } \\
\text { Code }\end{array}$ & $\begin{array}{l}\text { A historical perspective of the } \\
\text { formulation and development of } \\
\text { boiler code in the US, no real } \\
\text { technical data here }\end{array}$ \\
\hline WRI owned & E. Bullock & $\begin{array}{l}\text { Research and Development } \\
\text { of High Temperature } \\
\text { Materials for Industry }\end{array}$ & $\begin{array}{l}\text { Probably the best single text for } \\
\text { information on alloys for } \\
\text { gasification. Sections on the types } \\
\text { of materials themselves followed } \\
\text { by several chapters on use in } \\
\text { gasification and combustion } \\
\text { atmospheres. }\end{array}$ \\
\hline WRI owned & ASM & Materials Reference Book & $\begin{array}{l}\text { Excellent reference for } \\
\text { composition and performance data } \\
\text { for all alloys }\end{array}$ \\
\hline $\begin{array}{l}\text { TA430.M66 } \\
1985\end{array}$ & R. Morrell & $\begin{array}{l}\text { Handbook of Properties of } \\
\text { Technical and Engineering } \\
\text { Ceramics }\end{array}$ & Property data for ceramics \\
\hline $\begin{array}{l}\text { TA480.A6 } \\
\text { A6177 } 1993\end{array}$ & J. Davis & $\begin{array}{l}\text { ASM Aluminum and } \\
\text { Aluminum Alloys }\end{array}$ & Handbook \\
\hline $\begin{array}{l}\text { TA479.C37 } \\
\text { C37 } 1996\end{array}$ & J. Davis & $\begin{array}{l}\text { ASM Carbon and Alloy } \\
\text { Steels }\end{array}$ & Handbook \\
\hline $\begin{array}{l}\text { TA479.S7 S677 } \\
1994\end{array}$ & J. Davis & ASM Stainless Steels & Handbook \\
\hline $\begin{array}{l}\text { TA472.E63 } \\
1982\end{array}$ & ASM & $\begin{array}{l}\text { Engineering Properties of } \\
\text { Steels }\end{array}$ & Handbook \\
\hline $\begin{array}{l}\text { TA402.A86 } \\
1992\end{array}$ & J. Davis & $\begin{array}{l}\text { ASM Materials Engineering } \\
\text { Dictionary }\end{array}$ & $\begin{array}{l}\text { Definitions and descriptions of } \\
\text { materials terms }\end{array}$ \\
\hline $\begin{array}{l}\text { TS205.D64 } \\
1985\end{array}$ & L. Doyle & $\begin{array}{l}\text { Manufacturing Processes } \\
\text { and Materials for Engineers }\end{array}$ & $\begin{array}{l}\text { Basic engineering concepts and } \\
\text { metals manufacturing processes }\end{array}$ \\
\hline
\end{tabular}




\section{Library Quick Reference for Materials}

In general, books and literature dealing with materials can be found between TA400 and TA500.

\begin{tabular}{|l|l|}
\hline \multicolumn{1}{|c|}{ Subject } & \multicolumn{1}{c|}{ Library Reference Number } \\
\hline Engineering Design & TA174 \\
\hline Mathematical Modeling & TA200-TA350 \\
\hline Vibration & TA355 \\
\hline Fluid Mechanics & TA357 \\
\hline ASTM Standards & TA401 \\
\hline Engineering Materials & TA401 \\
\hline Strength of Materials & TA405 \\
\hline Fracture Mechanics & TA409 \\
\hline Non-destructive Evaluation & TA410 \\
\hline Creep & TA418 \\
\hline Fatigue & TA418.38 \\
\hline Wear & TA418.4 \\
\hline Corrosion & TA418.7, TA462 \\
\hline Composites & TA404.8, TA418.9, TA481 \\
\hline Cement & TA434 \\
\hline Plastics & TA455 \\
\hline ASM Metals Handbook & TA459 \\
\hline Stainless Steels & TA479 \\
\hline Welding & TA492 \\
\hline Joining & TA492 \\
\hline
\end{tabular}




\section{APPENDIX B}

Materials Notes:

\section{Critical Problems in Energy Production TA403 C74 1976}

1. Potential reactive elements in coal are $\mathrm{C}, \mathrm{H}, \mathrm{N}, \mathrm{O}, \mathrm{S}$, and $\mathrm{Cl}$.

2. The operations of importance are temperature, time, thermal cycling, erosion, stress, stress cycling, creep fatigue, stress corrosion cracking.

3. In oxidizing conditions, mild steels oxidize in dry $\mathrm{CO}_{2}$ environments much as they do in oxygen. Above $500^{\circ} \mathrm{C}$ in the presence of small amounts of water the corrosion rate is greatly accelerated. (add $\mathrm{Si}$ and lower water)

4. In reducing environments, carburization embrittlement occurs with diffusion of carbon.

5. Carbon monoxide dusting attack steels in range 500 to $700^{\circ} \mathrm{C}$.

6. Stress corrosion cracking in mild steels by dissolved $\mathrm{CO}_{2}$ as carbonic acid.

7. Hot corrosion can be due to sodium sulfate attack on nickel (add $\mathrm{Cr}$ and $\mathrm{Al}$ ).

8. $\mathrm{H}_{2} \mathrm{~S}$ aggravates stress corrosion cracking.

9. Sensitization of stainless steels with temperature and time involves instability of SS316 near $800^{\circ} \mathrm{C}$ due to carbide formation in grain boundaries.

10. Temper embrittlement caused by impurities, possibly phosphorus, precipitating in fixed temperature regions between $250-400^{\circ} \mathrm{C}$ or $450-600^{\circ} \mathrm{C}$.

11. Sigma phase formation

12. Gasification vessels under pressure require $25 \%$ Cr steels.

13. Historically pressure vessel design was at $25 \%$ yield strength plus corrosion allowance and aging factors.

14. Attack on refractory liners is by steam-hydrogen, carbon monoxide, carbon dioxide, and alkali vapors.

High Temperature Materials for Power Engineering Part 1

TA418.26 H53 1990

1. $\mathrm{NO}_{\mathrm{x}}$ less of a problem during gasification below $900^{\circ} \mathrm{C}$.

2. Ammonia injection with catalyst reduces $\mathrm{NO}_{\mathrm{x}}$. (Selective Catalytic Reduction SCR)

3. Adding limestone with coal acts as a sulfur sorbent that ends up in ash.

4. IN738 is a cast nickel superalloy for turbines?

5. Steam headers can be made from powder metallurgy.

6. Chromium increases corrosion resistance but can lower strength.

7. Largest material problem seen as super-heater/reheater air heater and uncooled hanger components resistance to oxidation and sulphidation.

8. Series $300 \mathrm{SS}$ okay to $650^{\circ} \mathrm{C}$ but above $900^{\circ} \mathrm{C}$, high chrome ferritic alloys necessary. However their lower strength means they must be used as claddings or unstressed.

9. Severe wear in fluidized bed heat exchangers a problem.

10. Main corrosion problems in coal gasifiers occur in gas cooling unit components. 
11. Some sulphidation at $0.5 \mathrm{~mm} / \mathrm{yr}$ at $800^{\circ} \mathrm{C}$ occurred above $0.2 \% \mathrm{H}_{2} \mathrm{~S}$ for $310 \mathrm{SS}$ $(25 \mathrm{Cr}-20 \mathrm{Ni})$ and $800 \mathrm{H}(20 \mathrm{Cr}-32 \mathrm{Ni})$. Aluminum in the alloy reduced sulphidation (3.5\%).

12. $\mathrm{HCl}$ values in MSW derived gas are 500 to $1000 \mathrm{mg} / \mathrm{nm}^{3}$.

13. Austenitic stainless steels survive from 2 to 10 times better than carbon steels in super-heaters and furnace walls.

14. Alloy AC66 (Ni31Cr26Nb0.6Ce0.05) better than Incoloy 800 for gasification atmosphere.

15. Haynes HR160 (NiCo29Cr28Si3) is good for sulphidation resistance.

16. Incoloy MA956 (FeCr20Al5Y0.5) for strength and oxidation resistance up to $1200^{\circ} \mathrm{C}$.

\section{Heat Resistant Materials II TA418.26 I533 1995}

1. The presence of stress leads to failure of a component in conditions where, based on its material properties, it would be expected to perform adequately.

2. HR 160 (NiCr28Co30Si2.6) is very resistant to sulphidation and oxidation at $600^{\circ} \mathrm{C}$ at least in unstressed conditions. NiCrFe alloys without Si were severely attacked by $\mathrm{H}_{2} \mathrm{~S}$.

3. Erosion corrosion occurs where moving particulates continuously may remove natural oxide scale on components leading to fast removal of material. Hard coatings may be more successful at preventing erosion than higher alloy materials.

4. A combination of high carbon and high chromium in an alloy can lead to large amounts of chromium carbide deposits at grain boundaries which gives low creep properties at high temperature. Additional aluminum in the alloy gives some corrosion resistance.

5. Silicon, which is added to improve sulphidation and carburization resistance adversely affects welding.

6. Improper welding of austenitic stainless steels without annealing to stress relieve can lead to hot cracking.

7. Giving a relative cost of SS310 of 1.0, $800 \mathrm{H}$ costs $1.5,600$ costs 2.2 and 625 costs 2.8.

8. A two layer corrosion coating on carbon steel consisting of Ni79Cr20Si1.5 below Fe26Si73 provided excellent protection in a combustion area near $900^{\circ} \mathrm{C}$.

9. What is the concentration effect of chlorine, sulfur and sodium with the Taylor Energy Reactor?

10. Haynes HR160 may be the alloy for the oxidation riser due to its strength, and corrosion resistant properties. Inconel 625 may be the second best choice.

\section{Ferritic Steels for High-Temperature Applications TA479.S7 A76 1983}

1. 9Cr2Mo ferritic steels used as super-heater tubes in a boiler at $19 \mathrm{MPa}$ and $571^{\circ} \mathrm{C}$ survived much better than 304SS and 321SS after six years with respect to hot corrosion. Tensile stayed high though Charpy values of all reduced after 1 year 
2. In coal gasification environments at $982^{\circ} \mathrm{C}$, some high $\mathrm{Cr}$ ferritic steels (446$\mathrm{Fe} 24 \mathrm{Cr}$ ) resisted corrosion better than 304SS and 310SS and as well as $800 \mathrm{H}$.

3. Ferritic 446 was also had much higher erosion corrosion resistance than $800 \mathrm{H}$.

\section{Coatings and Bimetallics for Aggressive Environments TA491.C66 1985}

1. Inconel 625 is specifically designed for high chlorides and other severe chemical environments.

2. Clad plate and co-extruded tubes can deal with two environments.

3. Grain refined TP347H SS can be used for high-pressure higher steam (4500 psi, $1150^{\circ} \mathrm{F}$ ) conditions in super-heater tubes.

\section{Research and Development of High Temperature Materials for Industry}

1. The upper temperature limit for ferritic steels is $570^{\circ} \mathrm{C}$.

2. At temperatures between $400^{\circ} \mathrm{C}$ and $570^{\circ} \mathrm{C}$ design use of ferritic steels is based on creep properties, where at lower temperature the design basis is time independent tensile properties.

3. Weldable ferritics have carbon less than $0.15 \%$.

4. Higher strength ferritics have carbon up to $0.3 \%$.

5. Welding ferritics can cause creep embrittlement.

6. Reduction of impurities can greatly improve ferritic steel performance.

7. Lowering sulfur content in ferritic steels improves ductility.

8. Low alloy CrMo steels have been used for weldable tubing and castings between 500 and $570^{\circ} \mathrm{C}$.

9. Higher alloy 9-12CrMo steels are strong and are useful for boiler tubing.

10. The use of austenitics in thick sections is only due to their corrosion resistance.

11. Co extruded materials can be used for super-heater tubes.

12. In lower temperature regions $\left(300-400^{\circ} \mathrm{C}\right)$ erosion can be a greater problem because there is insufficient heat to reform protective oxide layers.

13. Deposits on super-heaters may help against erosion but concentration of sulfur may lead to sulphidation.

14. Steam conditions $\left(540-570^{\circ} \mathrm{C}\right.$ and $16-24 \mathrm{Mpa}$ have been defined by the available materials.

15. While supercritical steam production requires better materials, IGCC gas turbines exit gas temperatures are below $600^{\circ} \mathrm{C}$ so materials for the steam power cycle is less an issue.

16. A gas turbine off gas temperature of $500^{\circ} \mathrm{C}$ is considered too low for economic steam turbine operation.

17. 50-60\% alumina concretes with calcium aluminate cements are recommended as refractory liners for dry ash gasifiers.

18. Water and steam lines should be purged during long down times to avoid corrosion in stagnant water.

\section{Component Reliability Under Creep Fatigue Conditions}


1. The useful practical limit of a pure metal is about one half of the melting point. Alloying can increase this value.

2. Interstitial substitution impedes dislocation movement and increases high temperature creep resistance.

3. Additional creep resistance can occur by dispersions of fine second phase particles. Over-aging of the precipitates may lead to excessive coarsening.

4. In a $2.25 \mathrm{CR}-1$ Mo steel after 88,000 hours at $550^{\circ} \mathrm{C}$ showed grain coarsening and precipitation of carbides at grain boundaries. Inter-granular cracking was the result.

\section{ASM Carbon and Alloy Steels}

1. Hydrogen has no known beneficial effects on steel, only detrimental effects.

2. Carbide forming elements such as chromium and molybdenum increase the resistance of steel to hydrogen attack.

3. Elements such as sulfur, vanadium, and sodium can change the nature of steel oxidation, sometimes increasing the rate to a level of inches per year.

4. Fluctuating steam temperatures lead to spalling and increased oxidation rates.

5. Ash deposition lowers surface oxygen partial pressure in addition to concentrating sodium and sulfur against the alloy surface.

\section{ASM Stainless Steels}

1. Resistance to sulfur increases with chromium and silicon content.

2. Austenitic co-extruded tubes are more resistant to fireside corrosion than carbon steels.

3. Molten alkalais may be responsible for superheater tube corrosion under ash deposits.

\section{Materials for Coal Gasification Power Plant}

1. Uncooled components suffer from severe carburization and sulphidation.

2. Cooled components operating below the dew point for syngas corrode due to $\mathrm{HCl}$ condensation.

3. Common boiler steels such as 13CrMo44 and 10CrMo910 suffer from sulphidation forcing the use of austenitic SS. 